\title{
In Celebration of University Faculty: The Promotion and Tenure Recognition Event
}

\author{
Christine Fischer, Mary Jane Conger, and Rosann Bazirjian*
}

$\mathrm{E}$ arning tenure and being promoted in the university setting should be reasons for celebration. Yet, all too often these milestones in the lives and careers of faculty get little celebratory notice. In the past, a few of the individual schools and the College at the University of North Carolina at Greensboro held mini-events in the spring to recognize the accomplishments of their own faculty. The University Libraries and the Office of the Provost decided to partner and hold a tenure attainment celebration for the entire campus.

This type of recognition is growing on campuses across the nation. Credit needs to be given to Paula Kaufman, ${ }^{1}$ University Librarian and Interim Chief Information Officer at the University of Illinois at Urbana-Champaign. She based their program on a similar program at the University of Tennessee at Knoxville. The Pennsylvania State University and the University of Wisconsin at Madison, among others, have also initiated similar programs. These programs celebrated tenure and promotion attainment, honored the faculty and their scholarly role, and recognized the importance of libraries in that process.

This article will describe the program as implemented at UNC Greensboro-how the team planned the program, hosted the event, created a Web site, used the American Library Association's READ posters software, and prepared the post-event display, what worked well and made the event a success as well as what was learned from the process will be discussed.

\section{General Description of the Program}

Each newly tenured and/or promoted faculty member is asked to select a special book for the University Libraries collection-a book that has special meaning to them and is of particular importance. A nameplate is placed in the book honoring the achievement of the individual. The faculty member is asked to provide a written statement describing why that book was selected. This statement is meant to provide a personal glimpse into the faculty member and to inspire students and others in their scholarly pursuits. A celebration is held in the fall with all of the books on display along with their written paragraphs. Wine and cheese are served, of course! The event is co-sponsored by the University Libraries and the Office of the Provost. A photo is also taken of each faculty member with their book, and that photo is placed on the READ posters developed by the American Library Association. The Libraries also create a Web site with the photos, books and explanatory descriptions of each book selected.

\section{Make Up of Team}

A Tenure Attainment Planning Team was appointed by the University Librarian to inaugurate this new program. The team was made up of eight individuals from various areas of the library and one team member from the Provost's Office for liaison work with that office. Each person brought different insights and talents. The Librarian for External Relations had hosted several functions for the University so his experience in that area was critical. An office assistant was instrumental in arranging meetings, sending out e-mails, collecting RSVPs, following up with honorees, and serving as the front line contact. The Heads of Acquisitions and Cataloging provided assistance in purchasing and cataloging the materials for the event. The Assistant Bindery Supervisor had produced many displays and quickly picked up the skills to artistically produce the READ posters. Another office assistant had previous experience with creating forms on the Web and managing a Web site. The Assistant Director for Collections \& Technical Services had worked in several different libraries and brought a broader perspective to the meetings. An administrative secretary with experience in working with food catering services and the student union became an ad hoc member to help with the reception.

\section{Initial Questions}

There were many questions that needed to be answered in order to move the program planning forward.

How and when to notify the honored faculty about this new program? It was decided that the first letter notifying the newly promoted and/or tenured faculty members would be sent out immediately after the Board of Trustees met to approve promotion and tenure recommendations and that the Provost's Office would send this out by mail. Team members wanted to include the time and place for the reception in this letter.

When to have the reception? In the spring after the Board of Governors voted on promotion and tenure candidates? In the early fall or late fall? The spring would be too rushed for faculty to decide on a book and write their paragraphs, and for the libraries to purchase and catalog books that were not already in the collection. Late fall tended to have many other events on and off campus. Early fall was decided upon.

What dates and venues were available when the Chancellor, Provost, and University Librarian could attend? The university calendar needed to be consulted to avoid conflicting with any big celebrations or events on campus that might mean fewer honorees could attend.

What time of day would attract the most attendees? The team wanted a day and time that the highest number of invitees would be available and willing to come to an event. Thursday was considered the best day, as Monday through Wednesday often had more evening classes. Friday was not considered as many faculty 
are able to leave early on that day. Late afternoon from 4:00-5:30 P.M. was considered best, as that allowed those who might have an evening class or childcare considerations to come to the early part of the reception. At the same time, those who had a late afternoon class or lab could come to the latter part of the reception.

Who to invite? There were 31 potential honorees depending on if they all were granted tenure and/or promotion. If each brought a guest there could be 62 people. Deans and department heads of the candidates, Provost, University Librarian, Chancellor, library liaisons, and team members were also to be invited. The best guess was between 100-120 people.

\section{Tasks to Be Done}

As the team continued to meet, a timeline and list of activities/ tasks that needed to be accomplished was developed.

- $\quad$ Prepare a calendar for the team (Appendix 1)

- Determine the form and content that communications with the honorees would take

- Design, print and send out invitations

- Design and print programs

- Take photos of candidates

- Mount photos and honorees' paragraphs on Web site

- $\quad$ Create READ posters

\section{Hearing from the Honorees}

Honorees were asked to complete a very simple e-mail form by entering their name, title and rank, the title and author (or editor) of their selected book, and the statement explaining their selection. The responses to the form were automatically distributed to the four team members whose tasks were to prepare the Web site and take photos of the honorees, assist with photography and create the READ posters, monitor participation and handle all correspondence, and manage the book ordering process.

\section{Acquisitions and Processing}

Responses from the honorees began arriving mid-May and continued to be sent through August, right up to the deadline for submission. Parameters for book selection included that the price be under $\$ 100$ and that the book was available domestically. As soon as the Head of Acquisitions received the notice about a faculty member's book selection, the library catalog was checked. If the book was held and its condition was very good, the book was taken to Preservation Services to have a bookplate applied. The book remained in Preservation Services to be available when a photo session was scheduled with the faculty member. Books were ordered if the title was not owned, if the condition of the locally owned copy was unacceptable, if a newer edition was available, or if the selected title was checked out. A "rush" note was added to the record and the honoree's name was included with a reference to promotion and tenure recognition; this ensured that the books would be singled out as they were received, cataloged, and processed.

A spreadsheet was maintained and shared as appropriate to monitor the selections and order process. Eight books in the collection could be used, one arrived as part of the approval plan and the two that were not yet published were expected to arrive via the approval program, so the library needed to purchase sixteen books. One title at $\$ 126.71$ went above the price limit, but ten were under $\$ 25.00$. The total cost of the purchased books was $\$ 502.44$.

Some titles were currently in print, while others were only available through out of print dealers. A couple of orders were cancelled by the supplier, adding to the amount of time it took to acquire the books. One faculty member selected a title housed in the Special Collections \& Rare Books Division. Since the book could not be checked out and a bookplate could not be applied to the inside cover, a second copy for the circulating collection was ordered in an edition available in print.

A University Libraries bookplate was produced for each book with the honoree's name and the year of recognition.

\section{Displays}

Preparing for the two displays required a significant amount of time. The main display was for the recognition event. Display cards were produced with the honoree's name, statement explaining why that title was selected, and photograph. For the event, the books were displayed for attendees to view. The day following the event, the display cards were mounted in display cases near the main entrance to Jackson Library. A scanned image of the book jacket was used in place of the books so that the actual books would be available for circulation. The description of the internal display included the Web address for the site on the libraries' home page. The library display was exhibited for two months.

\section{Web Site}

The University Libraries and the Provost's Office wanted an ongoing record of the honorees and their book selections. A Web site (http://library.uncg.edu/depts/admin/recognition/) was developed by a team member to provide that documentation. For several weeks around the time of the September celebration, the page was linked from the libraries' home page in the "Spotlight" section of rotating current event listings. The main page of the site, linked from the Administration departmental Web page, is a narrative description of the program. A link to the 2006 Honorees takes readers to the list of thirty faculty members' names and departments. The team was very pleased that only three of the 30 promoted or tenured faculty elected not to participate. Links to the book information for each participant are provided. A photo of the honoree holding the book is included for all who agreed to have a photograph taken. Besides serving as an archive of honorees and their selected books, the team sees the Web pages as a frame of reference for honorees in future years. For this inaugural event, faculty did not know what to expect when they were invited to participate. Each year a new link to honorees from that particular year will be added to the page.

\section{READ Posters}

Another purpose for taking photographs of the honorees with their books was to prepare a READ poster using ALA Graphics software. The team wanted to provide the faculty with a memento of the recognition event. A copy of the CD-ROM, which is used in conjunction with Photoshop, was purchased from the ALA Store. It offered a number of backgrounds and lettering options, which could be matched to such things as the subject's academic discipline, the book jacket, and the color of clothing worn. 
Only after books were purchased and received by the library was an appointment made to visit the faculty members in their offices for the photo shoot. Because the READ posters were planned as a surprise, the honorees were only told about the Web site. Several photos were taken with the faculty member in different poses holding the selected book.

The posters were printed by the University Graphics and Printing office at a very reasonable price, because the team selected the 12 " x 18 " size paper which could be reproduced on a standard printer. Because the honorees' names were a component of the poster, the personnel in that office were able to make labels with the names to seal them after the posters were wrapped in kraft paper. This packaging had the posters ready for pickup as faculty members left at the end of the celebration.

\section{Invitations and Program}

The team had decided earlier to invite the department head who had been in place at the time of the tenure/promotion decision not the current department head as of September. Also it was decided to invite all on the Deans Council, not just those deans who had an honoree on the list. All of the library liaisons (library faculty) would be invited. Only honorees were invited to bring a guest which meant there were two separate invitations, one for honorees and one for everyone else.

The program for the event was agreed upon. It was decided that there would only be short remarks from the Provost and University Librarian and that the Chancellor would also be invited to speak. Those remarks would be made about thirty minutes into the program to allow latecomers to hear what was said. The format for the written program was also decided at this time. There would be a list of the honorees with their department, names of those speaking and the Web site information where they and others could see the book selections and the paragraph about the book. When one honoree didn't want to participate in the event, it was decided that all the names would be listed in the program and on the Web site whether the person was participating or not; each individual had attained promotion and/or tenure. Arrangements were made to have a student musical group playing in the background during the reception.

\section{The Reception}

Two refreshment areas were set up for the reception, each with finger foods and wine. Seating was available. The display of books and accompanying photos and statements was arranged on tables along one wall. A final table held the wrapped posters.

For the event, a PowerPoint presentation was created to continuously run the READ posters in rotation on a screen at one side of the room. Attendees of the celebration were very enthusiastic about the pictures and were eager to see what backgrounds were used for their posters. A particular favorite was the poster of a music faculty member standing in front of a background of sheet music. Honorees and their guests talked about hanging their posters in such places as their offices or in their children's rooms. All were eager to find a location to display their gifts.
The formal program was brief, and conversation among attendees kept many people until the end of the reception.

\section{What Was Learned}

The diverse talents and knowledge of the planning team members were critical to success throughout the process.

- Administrative help from the Provost's Office and library administration for communications, distributing invitations, arranging meetings

- Someone gifted artistically to set up displays

- Web experience for developing the submission form and the Web site

- Good photographers willing to go to the honorees' offices

- A person knowledgeable about the ins and outs of hosting a campus event and who has worked with the printers

- Technical services staff who can institute procedures for ordering, purchasing, and cataloging new titles selected by honorees

- Following up on an ongoing basis ensured a high participation rate by honorees

- Photographing honorees in their offices was more convenient for faculty than asking them to make a trip to the campus photography studio

Timing is very tricky when distributing correspondence to faculty, especially at the end of an academic year and over the summer. It is crucial to develop a timeline and to follow it as closely as possible, while building time into the plan to allow for unforeseen interference. Coordination between the libraries and the Provost's Office is an important component of success.

In addition to other stipulations about the type of book an honoree could select, the title must be in print. Two faculty members chose titles not yet published. Their reasons for selecting the books were certainly valid, but in the future it will be specified that the books be available in print. Without the books in hand, the full process could not be completed in time for the recognition event.

The number of attendees able to participate in the event was far fewer than the number expected. Choosing a meeting room and arranging for food takes place fairly early in the process. The original estimation was based on full participation, which was unrealistic.

Rather than hoping to find a group to perform music gratis, it would be wise to budget funds to pay the musicians if live music is planned.

\section{Conclusion}

Honorees were grateful for the opportunity to celebrate their achievement and mentioned how glad they were about this new program. For the University Libraries the inaugural program was considered a success. It proved to be a valuable opportunity to recognize the contributions made by the faculty. 


\section{Appendix 1: Calendar for Promotion and \\ Tenure Recognition Program 2006}

\section{April 6}

Meeting of the Board of Trustees to approve promotion and tenure recommendations

April 14

Letter sent out from Provost's office (actually was sent out April 25)

April 28

E-mail letter sent out by University Librarian and the team asking for title of book to be received by August 18 (actually was e-mailed May 3)

July 1

Written letter from chair of the team sent to honorees reminding them of the August 18 deadline

August 14

Classes start

August 7

Invitations and programs sent to University Printers

\section{August 10}

E-mail to be sent by Provost's Office to any honorees who had not yet responded (not sent)

\section{August 17}

Only 10 people had not responded. Administrative Staff member sent one last e-mail reminding any faculty whose book title had not yet been received that information was needed by August 25 and there was no guarantee that if the title needed to be ordered that it would be ready in time for the reception.

\section{August 24}

Phone calls made to any faculty members who had not responded

\section{August 28}

Invitations sent out

September 18

Have materials acquired and cataloged

September 20

Date for RSVPs, follow up on those who did not respond

September 25

Last team meeting, give ARA final count of guests coming

September 28

2:00-4:00 Set up room, create display, set up slide show

4:00-5:30 Reception

5:30-6:00 Take down display

September 29

Set up display in Jackson Library lobby, prepare books to be sent to the stacks

\section{References}

${ }^{1}$ Special acknowledgment to Paula Kaufman,Interim Chief Information Officer,University of Illinois at Urbana-Champaign for the initial idea of tenure recognition programs. 